\title{
器 \\ Anthelmintic activity of Annona crassiflora leaves against Haemonchus contortus: part 1: in vitro inhibition of the hatchability and larval development
}

\author{
[Atividade antihelmíntica de folhas de Annona crassiflora contra Haemonchus contortus: parte 1: \\ inibição in vitro da eclodibilidade e do desenvolvimento larval]
}

\section{"Scientific Article/Artigo Científico"}

\author{
Marco Antonio Martins Caldeira ${ }^{1}$, Franciellen Morais-Costa ${ }^{1 *}$, Kaike Magno Macêdo ${ }^{1}$, Valdo \\ Soares Martins Júnior ${ }^{1}$, Dheison Emanuel Augusto Pereira ${ }^{1}$, Ana Cláudia Maia Soares ${ }^{2}$, \\ Isabela Parolis Martins ${ }^{1}$, Idael Matheus Goes Lopes ${ }^{1}$, Fernão Castro Braga ${ }^{3}$, \\ Neide Judith Faria Oliveira ${ }^{1}$, Eduardo Robson Duarte ${ }^{1}$
}

\begin{abstract}
${ }^{1}$ Instituto de Ciências Agrárias, Universidade Federal de Minas Gerais, Montes Claros-MG, Brasil.
${ }^{2}$ Departamento de Zootecnia, Universidade Estadual do Sudoeste da Bahia, Itapetinga-BA, Brasil.

${ }^{3}$ Departamento de Ciências Farmacêuticas, Universidade Federal de Minas Gerais Federal, Belo Horizonte-MG, Brasil.

*Autor para correspondência/Corresponding author: E-mail: franmoraisbio@gmail.com
\end{abstract}

\begin{abstract}
We evaluated the activity of Annona crassiflora leaves against Haemonchus contortus resistant to albendazol. Aqueous (AE), ethanolic (EE) and ethyl acetate (EAE) extracts were produced and the predominant presence of flavonoids was observed in HPLC-DAD chromatograms. Initially we evaluated the larval development inhibition (LDI) of dry A. crassiflora leaf powder or its AE directly in fecal quantitative cultures. The efficacies of the extracts, with or without tannins, on egg hatching inhibition (EHI) were investigated reveling that the EE was the most effective ( $\left.\mathrm{LC}_{90}=8.96 \mathrm{mg} / \mathrm{mL}\right)$. However, after tannin removal, AE showed the highest activity $\left(\mathrm{LC}_{90}=4.27 \mathrm{mg} / \mathrm{mL}\right)$. In the LDI test, the $\mathrm{LC}_{90}$ of AE was $<6.25 \mathrm{mg} / \mathrm{g}$ of fecal culture and to leaf powder of leaves was $69.14 \mathrm{mg} / \mathrm{g}$. High efficacies of AE and EE for EHI were detected and the tannins were not the main active metabolites. The anthelmintic potential of this plant could be attributed to association between flavonoids and other metabolites.
\end{abstract}

Keywords: Cerrado; nematode; flavonoids; quantitative coproculture.

\section{Resumo}

Avaliou-se a atividade de folhas de Annona crassiflora contra Haemonchus contortus resistentes ao albendazol. Extratos aquosos (EA), etanólicos (EE) e acetato de etila (EAE) foram produzidos e a presença predominante de flavonoides foi observada em cromatogramas HPLC-DAD. Inicialmente avaliou-se a inibição do desenvolvimento larval (IDL) do pó seco de folhas de A. crassiflora e seu EA diretamente em coproculturas quantitativas. As eficácias dos extratos, com ou sem taninos, na inibição da eclosão dos ovos (IEO) foram investigadas revelando que o $\mathrm{EE}$ foi o mais efetivo $\left(\mathrm{CL}_{90}=8,96 \mathrm{mg} / \mathrm{mL}\right)$. No entanto, após a remoção do tanino, o EA apresentou a maior atividade $\left(\mathrm{CL}_{90}=4,27 \mathrm{mg} / \mathrm{mL}\right.$ ). No teste IDL, a $\mathrm{CL}_{90}$ de EA foi $<6,25 \mathrm{mg} / \mathrm{g}$ na coprocultura e o pó desidratado das folhas foi de $69,14 \mathrm{mg} / \mathrm{g}$. A alta eficácia do EA e EE para IEO foram detectados e os taninos não foram os principais metabólitos ativos. O potencial anti-helmíntico dessa planta poderia ser atribuído à associação entre flavonoides e outros metabólitos.

Palavras-chave: Cerrado; nematódeo; flavonoides; coprocultura quantitativa.

\section{Introduction}

Gastrointestinal nematodes (GN) reduce weight gain (WG), meat, wool, and milk production of sheep (Miller et al., 2012). parasite in small ruminants reared in tropical and sub-tropical regions, promoting high mortality in lambs (Bastos et al., 2017). 
Most of the anthelmintics currently available on the market were developed after the 1960s and are essential in the control of $H$. contortus (Amarante and Sales, 2007). However, resistance to these products has been detected in GN of small ruminants on several continents (Raza et al., 2016; Bastos et al., 2017). The constant use of anthelmintics favors the selection of resistant populations, making it unfeasible to raise these animals in pastures (Santos et al., 2017).

Utilization of plants has provided alternatives for GN control (Githiori et al., 2005). The Cerrado biome occupies a large part of Central and South America and among its typical vegetal species, Annona crassiflora Mart. (Annonaceae), popularly known as "panã" or "araticum" is a tree species widely used by the human population for the nutritional value of its fruits (Araya, 2004). However, lambs that received aqueous extract (AE) of these seed for anthelmintic treatment presented diarrhea and severe lesions followed by death (Oliveira et al., 2011).

The AE of the Annona senegalensis Pers. shells significantly reduced $H$. contortus hatchability (Alawa et al., 2003), while the 50\% $\mathrm{AE}$ of Annona muricata leaves inhibited the hatching of this nematode with $84.91 \%$ efficacy (Ferreira et al., 2013). However, the anthelmintic effects of A. crassiflora extracts from leaves remain unknown. In this firth study, the aims were evaluated the effects of $A$. crassiflora leaves on the hatchability and larval development of $H$. contortus.

\section{Materials and Methods \\ Collection of plant material}

Young leaves were collected from eight individual adult $A$. crassiflora plants measuring a height of approximately $5 \mathrm{~m}$, in March 2016 in a rural community of Montes Claros, Minas Gerais, Brazil ( $\left.16^{\circ} 54^{\prime} 11^{\prime \prime} \mathrm{S}, 43^{\circ} 52^{\prime} 02^{\prime \prime} \mathrm{W}\right)$. The climate of this region is marked by a dry season from May to September and a rainy period in January and February and is classified as tropical wet with dry summer (As) according to the Köppen classification (Alvares et al., 2013).

Healthy leaves were selected and dried to constant weight in a forced air circulating dryer (TE 394/4, Tecnal Equipamentos Científicos, Piracicaba, SP, Brazil) at $40{ }^{\circ} \mathrm{C}$ for $72 \mathrm{~h}$. Dried leaves were ground in a Wiley mill (CE430/Macro, Cienlab, SP, Brazil) and stored in paper bags in darkness (Morais-Costa et al., 2015).
Plant samples were deposited in the Montes Claros Herbarium of Universidade Estadual de Montes Claros, as voucher specimen 3475.

\section{Extract production}

The aqueous extract (AE), ethanolic extract (EE) and ethyl acetate extract (EAE) were produced according to Morais-Costa et al. (2015). Sub-samples of all extracts were submitted to condensed tannin extraction according to the method proposed by Nyman et al. (1998). The supernatants were used to assess the effects of tannin-free extracts on egg hatching inhibition (EHI).

\section{Extract characterization}

We used a Waters Alliance 2695 HPLC system composed of a quaternary pump, an autosampler, a photodiode array detector (DAD) 2996, and a Waters Empower Pro data handling system (Waters Corporation, Milford, Connecticut, USA). The chromatograms were obtained at $210 \mathrm{~nm}$, and the UV spectra were recorded on-line from 190 to $400 \mathrm{~nm}$.

Total condensed tannin (proanthocyanidins) was according to the method described by Hiermann et al. (1986).

\section{Egg hatching inhibition}

A modified methodology of the hatchability inhibition test, proposed by the World Association for the Advancement of Veterinary Parasitology (Coles et al., 1992), was used to select the type of extract with better anthelmintic effect as described by Morais-Costa et al. (2016). Three Santa Inês lambs were infected with 2000 L3 of a strain albendazole-resistant $H$. contortus. This strain was obtained from sheep raised on a farm located in Montes Claros, Minas Gerais State, Brazil, which was treated with albendazole whit efficacies < $70 \%$. Only $H$. contortus L3 produced in fecal cultures made with samples obtained from those treated sheep, were used to infect worm-free lamb (Duarte et al. 2012). After 22 days, the lambs showed a mean fecal egg count (FEC) $>1500 / g$, determined using the modified McMaster technique (Gordon and Whitlock, 1939). Sedimentation in water, filtration, and flotation in saturated saline were conducted to obtain nematode eggs from lamb feces (Coles et al., 1992).

The experiments were performed in five replicates. Positive controls were exposed to levamisole phosphate $(0.3 \mathrm{mg} / \mathrm{mL})$ and the negative control was treated with sterile purified 
water. Experimental treatments using $A$. crassiflora extracts with tannins were performed at $168.5,84.3,42.1$, and $21.6 \mathrm{mg} / \mathrm{mL}$, and without tannins at 10.0, 5.0, 2.5, 1.3, and $0.6 \mathrm{mg} / \mathrm{mL}$.

In microwell plates ( 96 wells), we placed the mixtures comprising $100 \mu \mathrm{L}$ of egg suspension containing \pm 80 fresh eggs and $100 \mu \mathrm{L}$ of the extracts or controls (Nogueira et al., 2014, MoraisCosta et al., 2016).

The number of $\mathrm{L} 1$ relative to the initial number of eggs (remaining eggs plus L1) was determined for each replicate and subjected to variance analysis. Means were compared using Duncan's test $(P<0.05)$. Probit regression was used to estimate concentrations which inhibited 90\% ( $\left.\mathrm{LC}_{90}\right)$ of egg hatching, using SAEG 9.1 software. The formula of Coles et al. (1992) was used to determine the \% EHI:

$\% \mathrm{EHI}=100 \times(1-\mathrm{L} 1 /$ initial number of eggs $)$.

\section{Larval development inhibition in quantitative cultures}

We used the three lambs as described above which showed $2300 \pm 250$ FEC and $100 \%$ of Haemonchus spp. larvae after fecal cultures (Keith, 1953). Pooled feces were and immediately used in the quantitative coproculture test (Borges, 2003; Morais-Costa et al., 2016). The anthelmintic activity of the dried A. crassiflora leaf powder was evaluated at final concentrations of 83.3-333.3 $\mathrm{mg} / \mathrm{g}$ of fecal culture. The final concentration of $A$. crassiflora leaf powder was achieved by replacing the vermiculite. The AE was evaluated at 6.25-50.0 $\mathrm{mg} / \mathrm{g}$ of fecal culture. A solution of levamisole phosphate was used as a positive control $(0.3 \mathrm{mg} / \mathrm{g})$ and sterile distilled water was the negative control.

The feces were collected directly from the rectal ampulla and all concentrations and the controls were evaluated in five replicates, which were incubated in a refrigerated chamber at $28{ }^{\circ} \mathrm{C}$ for 7 days (Nery et al, 2010; Morais-Costa et al., 2016).

The number of LPGF (L3/feces) was counted in a Sedgewick chamber with an optical microscope at 100x. The percent LDI was calculated according to the formula adapted from Borges (2003):

$\%$ LDI $=100 \times(1-$ LPGF of the treated group/LPGF of the untreated group).

The values of LPGF were transformed into $\log _{10}(\mathrm{x}+10)$ and subjected to analysis of variance (ANOVA). Means were compared with Duncan's test and probit regression was used in the estimation of $\mathrm{LC}_{90}$ at $5 \%$ significance using SAEG 9.1 software.

\section{Results \\ Secondary metabolites of Annona crassiflora leaves}

Chromatograms recorded by HPLC-DAD showed a similarity in the profiles of $\mathrm{AE}, \mathrm{EE}$ and EAE, with a predominance of peaks corresponding to polar compounds, and UV spectra compatible with polyphenols (Figure 1A, B, and C). The two highest peaks observed indicated retention times of 6.980 and 7.731, 6.484 and 7.704, and 9.644 and $36.323 \mathrm{~min}$ for EA (Figure 1A), EE (Figure 1B), and EAE (Figure IC), respectively.
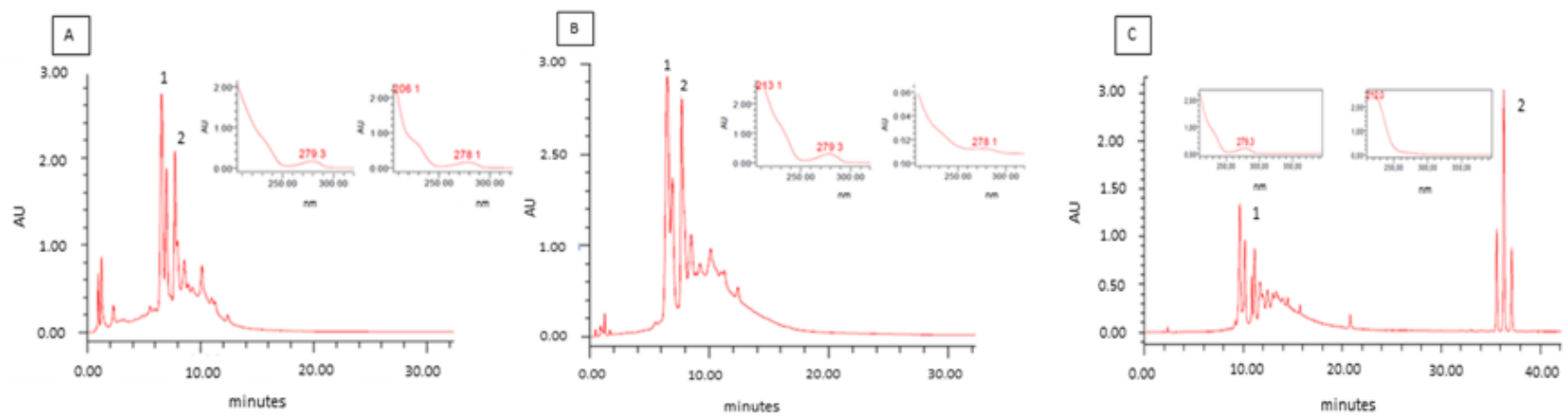

Data from the UV spectra were compatible with flavonoids ( $K 279.3$ and $278.1 \mathrm{~nm}$ for $\mathrm{AE}$ (Figure 1A) and EE (Figure1 B), respectively, and K 279.3 and $212.0 \mathrm{~nm}$ for EAE (Figure 1C). The condensed tannin concentrations of $\mathrm{AE}, \mathrm{EE}$ and
EAE were $6.93 \%, 12.05 \%$, and $0.64 \%$, respectively.

\section{Egg hatching inhibition}

Egg hatching inhibition increased along with the concentration of the all extracts. For the $\mathrm{AE}$ with and without tannin, concentrations $\geq 10.53$ 
and $2.5 \mathrm{mg} / \mathrm{mL}$, respectively, and presented significantly lower average number of hatched larvae than the negative controls (Table 1). The
$\mathrm{LC}_{90}$ for the extract with tannin was $85.48 \mathrm{mg} / \mathrm{mL}$ (95\% CI: confidence interval 76.03-97.85) and $4.27 \mathrm{mg} / \mathrm{mL}$ (95\% CI: 4.05-4.53) for the extract without tannin.

Table 1. Averages of blastomered eggs, embryonated eggs, Haemonchus contortus L1 Larvae and efficacy of aqueous extract of Annona crassiflora Mart. (Annonaceae) leaves with and without tannins.

\begin{tabular}{|c|c|c|c|c|c|}
\hline $\begin{array}{c}\begin{array}{c}\text { Concentration } \\
\mathrm{mg} / \mathrm{ml}\end{array} \\
\end{array}$ & Blastomered eggs & $\begin{array}{c}\begin{array}{c}\text { Embryonated } \\
\text { eggs }\end{array} \\
\end{array}$ & $\begin{array}{c}\text { Larvae } \\
\text { L1 }\end{array}$ & $\begin{array}{c}\text { Eggs + } \\
\text { Larvae }\end{array}$ & $\begin{array}{c}\text { Efficacy } \\
(\%)^{*}\end{array}$ \\
\hline \multicolumn{6}{|l|}{ With tannin } \\
\hline 168.5 & $21.2^{\mathrm{c}}$ & $4.2^{\text {cde }}$ & $2.0^{\mathrm{f}}$ & 27.4 & 97.2 \\
\hline 84.3 & $33.2^{b}$ & 2.2 ef & $9.5^{\mathrm{e}}$ & 45.0 & 86.6 \\
\hline 42.1 & $36.8^{b}$ & $2.5^{\mathrm{de}}$ & $12.5^{\mathrm{e}}$ & 51.8 & 82.6 \\
\hline 21.0 & $25.3^{\mathrm{c}}$ & $6.0^{\mathrm{c}}$ & $35.7^{\mathrm{d}}$ & 67.0 & 49.6 \\
\hline 10.53 & $12.8^{\mathrm{d}}$ & $4.0^{\text {cde }}$ & $46.5^{c}$ & 63.3 & 34.5 \\
\hline \multicolumn{6}{|l|}{ Without tannins } \\
\hline 10.0 & $3.5^{\mathrm{e}}$ & $44.0^{\mathrm{b}}$ & $0.0^{\mathrm{f}}$ & 47.5 & 100.0 \\
\hline 5.0 & $2.5^{\mathrm{e}}$ & $55.2^{\mathrm{a}}$ & $0.0^{\mathrm{f}}$ & 57.7 & 100.0 \\
\hline 2.5 & $1.2^{\mathrm{e}}$ & $2.0^{\mathrm{ef}}$ & $49.5^{c}$ & 52.7 & 30.3 \\
\hline 1.3 & $0.7^{\mathrm{e}}$ & $5.3^{\mathrm{cd}}$ & $67.0^{\mathrm{b}}$ & 73.0 & 5.6 \\
\hline 0.6 & $1.0^{\mathrm{e}}$ & $3.0^{\mathrm{de}}$ & $73.2^{\mathrm{a}}$ & 77.2 & --- \\
\hline Levamisol & $85.0^{\mathrm{a}}$ & $0.0^{\mathrm{f}}$ & $0.0^{\mathrm{f}}$ & 85.0 & 100.0 \\
\hline Untreated & $0^{\mathrm{e}}$ & $0^{\mathrm{f}}$ & $71.0^{\mathrm{a}}$ & 71.0 & --- \\
\hline $\mathrm{CV}(\%)$ & 23.1 & 18.2 & 9.8 & & \\
\hline
\end{tabular}

Different lower case letters indicate significant differences $(\mathrm{p}<0.05)$ by Duncan'test

(CV) Coefficient of variation,

$* \%$ efficacy $=100 \times(1-$ mean of L1/ mean eggs + L1 $)$

For EE and EAE, with and without tannin, concentrations $\geq 21.6$ and $1.3 \mathrm{mg} / \mathrm{mL}$, respectively, and showed lower $(P<0.05)$ hatched larvae averages than the negative controls (Table 2 and 3 ). For EE with and without tannin, the $\mathrm{LC}_{90}$ was 8.95 (95\% CI: $1.49-1.32)$ and $7.98 \mathrm{mg} / \mathrm{mL}$ (95\% CI: 7.28-8.86), respectively. However, EAE showed a greater variation in $\mathrm{LC}_{90}$ values, with concentrations of $81.83 \mathrm{mg} / \mathrm{mL}$ (95\% CI: 73.30 92-75) with tannin and $4.84 \mathrm{mg} / \mathrm{mL}$ (95\% CI: 4.515.22) without tannin. There was a linear reduction in the number of eggs and larvae detected in the EHI test, which was inversely related to the concentration of the extracts.

Table 2. Averages of blastomered eggs, embryonated eggs, Haemonchus contortus L1 Larve and efficacy of ethanolic extract of Annona crassiflora Mart. (Annonaceae) leaves with and without tannins.

\begin{tabular}{|c|c|c|c|c|c|}
\hline $\begin{array}{c}\text { Concentration } \\
\mathrm{mg} / \mathrm{ml}\end{array}$ & Blastomered eggs & Embryonated eggs & $\begin{array}{c}\text { Larvae } \\
\text { L1 }\end{array}$ & $\begin{array}{l}\text { Eggs + } \\
\text { Larvae }\end{array}$ & $\begin{array}{c}\text { Efficacy } \\
(\%)^{*}\end{array}$ \\
\hline \multicolumn{6}{|l|}{ With tannin } \\
\hline 337.0 & $0.0^{\mathrm{e}}$ & $0.0^{\text {ef }}$ & $0.0^{\mathrm{e}}$ & 0.0 & 100.0 \\
\hline 168.5 & $31.8^{b}$ & $4.0^{\mathrm{d}}$ & $1.5^{\mathrm{d}}$ & 37.3 & 97.4 \\
\hline 84.3 & $3.5^{\mathrm{e}}$ & $4.0^{\mathrm{d}}$ & $2.5^{\mathrm{d}}$ & 10.0 & 95.7 \\
\hline 42.1 & $3.3^{\mathrm{e}}$ & $4.5^{\mathrm{cd}}$ & $3.0^{\mathrm{d}}$ & 10.8 & 94.8 \\
\hline 21.6 & $3.3^{\mathrm{e}}$ & $3.5^{\mathrm{d}}$ & $3.8^{\mathrm{d}}$ & 10.6 & 93.5 \\
\hline \multicolumn{6}{|l|}{ Without tannins } \\
\hline 10.0 & $11.5^{\mathrm{c}}$ & $37.8^{\mathrm{a}}$ & $4.0^{\mathrm{d}}$ & 53.3 & 93.1 \\
\hline 5.0 & $3.0^{\mathrm{e}}$ & $6.3^{c}$ & $11.8^{\mathrm{d}}$ & 21.1 & 79.8 \\
\hline 2.5 & $1.0^{\mathrm{f}}$ & $1.0^{\mathrm{e}}$ & $29.0^{c}$ & 31.0 & 40.5 \\
\hline 1.3 & $0.0^{\mathrm{f}}$ & $0.0^{\mathrm{e}}$ & $44.5^{b}$ & 44.5 & 23.3 \\
\hline 0.6 & $0.0^{\mathrm{d}}$ & $0.0^{\mathrm{e}}$ & $56.5^{\mathrm{a}}$ & 56.5 & 2.5 \\
\hline Levamisol & $50.3^{\mathrm{a}}$ & $0.0^{\mathrm{e}}$ & $0.0^{\mathrm{d}}$ & 50.3 & 100 \\
\hline Untreated & $0^{\mathrm{f}}$ & $0^{\mathrm{e}}$ & $58.0^{\mathrm{a}}$ & 58.0 & --- \\
\hline $\mathrm{CV}(\%)$ & 10.5 & 16.2 & 15.7 & & \\
\hline
\end{tabular}

Different lower case letters indicate significant differences $(\mathrm{p}<0.05)$ by Duncan'test

(CV) Coefficient of variation,

$* \%$ efficacy $=100 \times(1-$ mean of L1/ mean eggs + L1 $)$ 


\section{Inhibition of larval development}

The treatment with dehydrated A. crassiflora leaves or its $\mathrm{AE}$ reduced the mean number of infective larvae when compared to the negative control $(P<0.05$, table 4$)$. For $\mathrm{AE}$, the $\mathrm{LC}_{90}$ was not estimated because all concentrations evaluated showed $100 \%$ of efficacy to reduce the larval development. The anthelmintic efficacy increased with leaf concentration of power leaves and the estimated $\mathrm{LC}_{90}$ was $69.14 \mathrm{mg} / \mathrm{g}$ of fecal culture.

Table 3. Averages of blastomered eggs, embryonated eggs, Haemonchus contortus L1 Larve and efficacy of ethyl acetate extract of Annona crassiflora Mart. (Annonaceae) leaves with and without tannins.

\begin{tabular}{|c|c|c|c|c|c|}
\hline $\begin{array}{c}\begin{array}{c}\text { Concentration } \\
\mathrm{mg} / \mathrm{ml}\end{array} \\
\end{array}$ & Blastomered eggs & $\begin{array}{c}\begin{array}{c}\text { Embryonated } \\
\text { eggs }\end{array} \\
\end{array}$ & $\begin{array}{c}\text { Larvae } \\
\text { L1 }\end{array}$ & $\begin{array}{c}\text { Eggs + } \\
\text { Larvae }\end{array}$ & $\begin{array}{c}\text { Efficacy } \\
(\%)^{*}\end{array}$ \\
\hline \multicolumn{6}{|l|}{ With tannin } \\
\hline 337.0 & $0^{\mathrm{e}}$ & $0^{\text {ef }}$ & $0^{\mathrm{e}}$ & 0 & 100.00 \\
\hline 168.5 & $0^{\mathrm{e}}$ & $0^{\text {ef }}$ & $1.6^{\mathrm{e}}$ & 1.6 & 95.43 \\
\hline 84.3 & $5.8^{b}$ & $0.8^{\text {ef }}$ & $3.0^{\mathrm{e}}$ & 9.6 & 91.43 \\
\hline 42.1 & $1.8^{\mathrm{d}}$ & $1.8^{\mathrm{d}}$ & $9.6^{\mathrm{d}}$ & 13.2 & 72.57 \\
\hline 21.0 & $3.4^{\mathrm{c}}$ & $3.4^{\mathrm{c}}$ & $10.8^{\mathrm{cd}}$ & 17.6 & 69.14 \\
\hline \multicolumn{6}{|l|}{ Without tannins } \\
\hline 10.0 & $2.0^{\mathrm{d}}$ & $10.2^{\mathrm{b}}$ & $0.6^{\mathrm{e}}$ & 12.8 & 98.28 \\
\hline 5.0 & $1.8^{\mathrm{d}}$ & $1.4^{\mathrm{de}}$ & $2.6^{\mathrm{e}}$ & 5.8 & 92.57 \\
\hline 2.5 & $2.4^{\mathrm{cd}}$ & $1.4^{\mathrm{de}}$ & $13.0^{\mathrm{c}}$ & 16.8 & 62.85 \\
\hline 1.3 & $2.8^{\mathrm{cd}}$ & $0.4^{\text {def }}$ & $2.6^{b}$ & 5.8 & 25.71 \\
\hline 0.6 & $2.0^{\mathrm{d}}$ & $1.0^{\mathrm{def}}$ & $33.4^{\mathrm{a}}$ & 36.4 & 4.57 \\
\hline Levamisol & $13.8^{\mathrm{a}}$ & $22.0^{\mathrm{a}}$ & $0^{\mathrm{e}}$ & 35.8 & 100.00 \\
\hline Untreated & $0^{\mathrm{e}}$ & $0^{\mathrm{f}}$ & $35^{\mathrm{a}}$ & 35.0 & --- \\
\hline $\mathrm{CV}(\%)$ & 32.84 & 28.60 & 18.93 & & \\
\hline
\end{tabular}

Different lower-case letters indicate significant differences $(\mathrm{p}<0.05)$ by Duncan'test

(CV) Coefficient of variation,

$* \%$ efficacy $=100 \times(1-$ mean of L1/ mean eggs + L1 $)$

Table 4. Mean values Haemonchus contortus infecting larvae from treated coprocultures with different concentrations of the dehydrated leaf or aqueous extract of Annona crassiflora Mart. (Annonaceae), with levamisol $(0.025 \mathrm{mg} / \mathrm{g})$ or untreated.

\begin{tabular}{lll}
\hline \multicolumn{1}{c}{ Treatments $(\mathbf{m g} / \mathbf{g})$} & \multicolumn{1}{c}{ LDGF $^{*}$} & \multicolumn{1}{c}{ Efficacy (\%)** } \\
\hline 333.3 & $12.0 \pm 1.8^{\mathrm{d}}$ & 99.72 \\
250.0 & $10.0 \pm-1.5^{\mathrm{d}}$ & 99.76 \\
166.6 & $38.0 \pm-5.32^{\mathrm{c}}$ & 99.12 \\
83.3 & $90.0 \pm-14.4^{\mathrm{b}}$ & 97.91 \\
Untreated & $4325.0 \pm-646.75^{\mathrm{a}}$ & -- \\
Levamisol $(0.025 \mathrm{mg} / \mathrm{g})$ & $0.00 \pm-0.0^{\mathrm{d}}$ & 100.00 \\
\hline
\end{tabular}

* LDGF: Number of infective larvae (L3)/g feces.

Different letters in the columns indicate significant differences by the Duncan test with $\mathrm{P}<0.05$.

$* *$ Efficacy $(\%)=100 \times(1-$ LPGF of the treated group/LPGF of the untreated group), adapted from Borges (2003).

\section{Discussion}

Haemonchus contortus infections in sheep herds can lead to several negative effects, such as an increase in production cost (Miller et al., 2012). The emergence of multi-drug resistant nematode populations has prompted a significant effort to find alternatives to conventional anthelmintic medicines. In this study, the leaf extracts of $A$. crassiflora, a tree common to the Cerrado, showed significant EHI and LDI efficacy against $H$. contortus. HPLC analysis revealed the presence of flavonoids in the leaf extracts, which mantained EHI activity, even after tannin removal.
The extracts containing tannins showed differences in EHI efficacy, with EE that showed the most being the most effective ( $\mathrm{LC}_{90} 8.96$ $\mathrm{mg} / \mathrm{mL}$ ). However, after tannin removal, AE was the more effective extract ( $\mathrm{LC}_{90} 4.27 \mathrm{mg} / \mathrm{mL}$ ). For $\mathrm{AE}$ and $\mathrm{EAE}$ without the presence of tannins, substantial reduction of $\mathrm{LC}_{90}$ was verified, increasing the EHI efficacy, which suggests the presence of other metabolites effective in the inhibition of embryogenesis and hatchability.

These results suggest that flavonoids, the presence of which was confirmed in the chromatograms, were the metabolites primarily responsible for this anthelmintic effect. In other 
Annonaceae plants evaluated, the most frequent flavonoids were the O-glycosides of apigenin, kaempferol, quercetin and luteolin (Santos and Salatino, 2000). Other investigations involving species of the Annona genus have shown lower efficacies than those observed for A. crassiflora extracts. The methanolic extract of Annona squamosa bark at $6.25 \mathrm{mg} / \mathrm{mL}$ demonstrated an EHI efficacy of $77.4 \%$ (Kamaraj and Rahuman, 2011) and Ferreira et al. (2013) reported an efficacy of $84 \%$ for $\mathrm{AE}$ of A. muricata leaves at $50 \%$ final dilution.

Our results clearly demonstrated elevation of EHI efficacy after tannin removal from EA and EAE of A. crassiflora leaves, signified by reductions of their $\mathrm{LC}_{90}$ values. This observation was also verified in the study of other plants of the Brazilian Cerrado. The hydroalcoholic extracts of Turnera ulmifolia leaves showed the highest EHI. The inhibitory effects this extract was blocked by tannin removal (Oliveira et al., 2017).

The study of $\mathrm{AE}$ and $\mathrm{EE}$ derived from Piptadenia viridiflora leaves, a common tree of the Cerrado, showed the presence of flavonoids in HPLC chromatograms. In EHI tests, the $\mathrm{LC}_{90}$ of AE was $2.4 \mathrm{mg} / \mathrm{mL}$, and of $\mathrm{EE}$ was $2.1 \mathrm{mg} / \mathrm{mL}$. Similarly, after tannin extraction, higher EHI was observed (Morais-Costa et al., 2016).

In analyzing the larval exsheathment inhibition (LEI) activity of plant extracts, the flavonoids naringenin, quercetin, and luteolin showed high efficacy at $250 \mu \mathrm{M}$. These metabolites presented synergistic effects enhancing the LEI activity of procyanidin tannins (Klongsiriwet et al., 2015). African browse plant extracts showed high LEI activity, resulting from the presence of both phenolic and non-phenolic compounds. The concentration of condensed tannins was not necessarily related to the anthelmintic properties of the extracts against L3 H. contortus (Mengistu et al., 2017).

The flavonoid's anthelminitic effects and their synergism with other plant compounds have not yet been fully understood. However, their action may be attributed to their effects on enzyme activity and metabolic processes in parasites (Kerboeuf et al., 2008). In this research were verified the reduction of parasitic structures, which were inversely proportional to the concentration of the extracts of A. crassiflora leaves. This was also observed with the AE extract of Genipa americana leaves (Nogueira et al., 2014), the reduction of eggs and larvae that possibly was action of the enzymes as proteases.

The A. crassiflora leaf powder demonstrated notable LDI activity at $69.14 \mathrm{mg} / \mathrm{g}$ of fecal culture. However, the AE showed better efficacy because its $\mathrm{LC}_{90}$ was $<6.25 \mathrm{mg} / \mathrm{g}$ of fecal culture. These results indicated the metabolites of these leaves exhibiting the anthelmintic efficacy under natural conditions, because these substances were evaluated together with feces, where naturally occur the hatching and the larval development of GN as reported by Nery et al. 2010 and MoraisCosta et al. 2016.

Among other Cerrado species, LDI efficacies have been reported in fecal culture. Aqueous extract of Caryocar brasiliense peel at $200 \mathrm{mg} / \mathrm{mL}$ inhibited $94.8 \%$ of $H$. contortus larval development in fecal cultures, and phytochemical tests indicated the presence of catechins, steroids, flavonoids, saponins, xanthones, and tannins (Nogueira et al., 2012). Ximenia americana has low condensed tannin content $(0.3 \%)$ and the major peaks of UV spectra in HPLC chromatograms are indicative of flavonoids in this species' leaf extracts. The AE of this plant at $333.3 \mathrm{mg} \mathrm{dw} / \mathrm{g}$ of fecal culture demonstrated 99.8\% LDI (MoraisCosta et al., 2015). The $\mathrm{LC}_{90}$ of AE of Pipadenia viridiflora leaves for LDI was only $13.6 \mathrm{mg} / \mathrm{g}$ and this extract showed low condensed tannin content $(0.2 \%)$ and the UV data in HPLC analyze compatible with flavonoids (Morais-Costa et al., 2016), reinforcing the hypothesis that flavonoids may also act as inhibitors of nematode larval development.

\section{Conclusion}

Leaf extracts of A. crassiflora show the presence of flavonoids and high EHI and LDI activity against $H$. contortus resistant to albendazol. Tannins were not shown to be the principal components affecting EHI, hence it is necessary to isolate and characterize the principal active $A$. crassiflora compounds, and to assess their possible synergism

\section{Conflict of interest}

The authors of this manuscript have no financial or personal relationship with individuals or organizations that could influence or bias the content of the paper. 


\section{Ethics Committee}

The research project was approved by the ethics committee of the Ethics Committee on the use of animals (CEUA) of the Federal University of Minas Gerais, Brazil, under number 275/2013.

\section{Acknowledgements}

National Council for Scientific and Technological Development (CNPq), financial support and scholarships provided by the Foundation for Research Support of Minas Gerais (FAPEMIG), Coordination of Improvement of Higher Education Personnel (CAPES), and ProRectory Research of Universidad Federal de Minas Gerais (PRPq-UFMG).

\section{References}

Alawa, C.B.I., Adamu, A.M., Gefu, J.O., Ajanusi, O.J., Abdu, P.A., Chiezey, N.P., Alawa, J.N., Bowman D.D. In vitro screening of two Nigerian medicinal plants (Vernonia amygdalina and Annona senegalensis) for anthelmintic activity. Veterinary Parasitology, 113(1): 73-81, 2003.

Alvares, C.A.; Stape, J.L.; Sentelhas, P.C.; Gonçalves, J.L.M.; Sparovek, G.; Köppen's climate classification map for Brazil. Meteorologische Zeitschrift, 22(6): 711728, 2013.

Amarante, A.F.T.; Sales, R.O. Controle de endoparasitoses dos ovinos: uma revisão. Revista Brasileira de Higiene e Sanidade Animal, 1(2): 14-36, 2007.

Araya, H. Studies on annonaceous tetrahydrofuranic acetogenins from Annona squamosa L. seeds. National Institute for Agro-Environmental Sciences, 23, 77-149. 2004.

Bastos, G.A.; Fonseca, L.D.; Ferreira, A.V.P.; Costa, M.A.M.S.; Silva, M.L.F.; Vasconcelos V.O.; Sousa, R.M.; Duarte, E.R. Helminthiasis characterization and anthelmintic efficacy for ewes and lambs raised in tropical semiarid region. Tropical Animal Health and Production, 49(5): 937943, 2017.

Borges. C.C.L. Atividade in vitro de antihelmínticos sobre larvas infectantes de nematódeos gastrintestinais de caprinos, utilizando a técnica de coprocultura quantitativa (Ueno, 1995). Parasitología Latinoamericana, 58(3-4), 142-147. 2003.
Coles, G.C.; Bauer, C.; Borgsteede, F.H.; Geerts, S.; Klei, T.R.; Taylor, M.A.; Waller, P.J. World association for the advancement of veterinary parasitology (WAAVP) methods for the detection of anthelmintic resistance in nematodes of veterinary importance. Veterinary Parasitology, 44(1-2): 35-44, 1992.

Duarte, E.R.; Silva, R.B.; Vasconcelos, V.O.; Nogueira, F.A.; Oliveira, N.J.F. Diagnóstico do controle e perfil de sensibilidade de nematoides de ovinos ao albendazol e ao levamisol no norte de Minas Gerais. Pesquisa Veterinária Brasileira. 32, 147-152, 2012.

Ferreira, L.E.; Castro, P.M.N.; Chagas, A.C.S.; França, S.C.; Beleboni, R.O. In vitro anthelmintic activity of aqueous leaf extract of Annona muricata L (Annonaceae) against Haemonchus contortus from sheep. Experimental Parasitolology, 134(3): 327332. 2013.

Githiori, J.B.; Hoglund, J.; Waller, P.J. Ethnoveterinary plants preparations as livestock dewormers: practices, popular beliefs, pitfalls and prospects for the future. Animal Health Research Reveiews, 6(1): 91-103, 2005.

Gordon, H.McL.; Whitlock, A.V. A new technique for counting nematode eggs in sheep feces. Journal Council for Scientific and Industrial Research, 12(1): 50-52, 1939.

Hiermann, A.; Kartnig, T.H.; Azzam, S.M. Ein Beitrag zur quantitativen Bestimmung der Procyanidine in Crataegus. Scientia Pharmaceutica, 54: 331-337, 1986.

Kamaraj, C.; Rahumann, A.A. Efficacy of anthelmintic properties of medicinal plant extract against Haemonchus contortus. Research in Veterinary Science, 91(3): 400404, 2011.

Keith, R.K. The differentiation of infective larvae of some common nematode parasites of cattle. Australian Journal of Zoology, 1: 223-235, 1953.

Kerboeuf, D.; Riou, M.; Guégnard, F. Flavonoids and related compounds in parasitic disease control. Mini Reviews in Medicinal Chemistry, 8(2); 116-128, 2008.

Klongsiriwet, C.; Quijada, J.; Williams, A.R.; Mueller-Harvey, I.; Williamson, E.M.; Hoste, H. Synergistic inhibition of Haemonchus contortus exsheathment by flavonoid monomers and condensed 
tannins. International Journal for Parasitology: Drugs and Drug Resistance, 5(3): 127-134, 2015.

Mengistu, G.; Hoste, H.; Karonen, M.; Salminen, J.P.; Hendriks, W.H.; Pellikaan, W.F. The in vitro anthelmintic properties of browse plant species against Haemonchus contortus is determined by the polyphenol content and composition. Veterinary Parasitology, 237: 110-116, 2017.

Miller, C.M.; Waghorn, T.S.; Leathwick, D.M.; Candy, P.M.; Oliver, A.M.B.; Watson, T.G. The production cost of anthelmintic resistance in lambs. Veterinary Parasitology 186(3-4): 376-381, 2012.

Morais-Costa, F.; Bastos, G.A.; Soares, A.C.M.; Costa, E.G.L.; Vasconcelos, V.O.; Oliveira, N.J.F.; Braga, F.C.; Lima, W.S.; Duarte, E.R. In vitro and in vivo action of Piptadenia viridiflora (Kunth) Benth against Haemonchus contortus in sheep. Veterinary Parasitology, 223(15): 43-49, 2016.

Morais-Costa, F.; Soares, A.C.M.; Bastos, G.A.; Nunes, Y.R.; Geraseev, L.C.; Braga, F.C.; Lima, W.S.; Duarte, E.R. Plants of the Cerrado naturally selected by grazing sheep may have potential for inhibiting development of Haemonchus contortus larva. Tropical Animal Health and Production, 47(7): 1321-1328, 2015.

Nery, P.S.; Nogueira, F.A.; Martins, E.R.; Duarte, E.R. Effect of Anacardium humile on the larval development of gastrintestinal nematodes of sheep. Veterinary Parasitology, 171(3-4): 361-364, 2010.

Nogueira, F.A.; Nery, P.S.; Morais-Costa, F.; Oliveira, N.J.F.; Martins, E.R.; Duarte, E.R. Efficacy of aqueous extracts of Genipa Americana L. (Rubiaceae) in inhibiting larval development and eclosion of gastrointestinal nematodes of sheep. Journal of Applied Animal Research, 42: 356-360, 2014.

Nogueira, F.A.; Fonseca, L.D.; Silva, R.B.; Ferreira, A.V.P.; Nery, P.S.; Geraseev, L.C.;
Duarte, ER. In vitro and in vivo efficacy of aqueous extract of Caryocar brasiliense Camb to control gastrointestinal nematodes in sheep. Parasitology Research, 111(1): 325330, 2012.

Nyman, U.; Joshi, P.; Madsen, L.B.; Pinstrup, M.; Rajasekharan, S.; George, V.; Pushpangadan, P. Ethnomedical information and in vitro screening forangiotensin-converting enzyme inhibition of plants utilized as traditionalmedicines in Gujarat, Rajasthan and Kerala (India). Journal Ethnopharmacology, 60(3): 247-263, 1998.

Oliveira, A.F.; Costa Junior, L.M.; Lima, A.S.; Silva, C.R.; Ribeiro, M.N.; Mesquista, J.W.; Rocha, C.Q.; Tangerina, M.M.; Vilegas, W. Anthelmintic activity of plant extracts from Brazilian savana. Veterinary Parasitology, 236: 121-127, 2017.

Oliveira, N.J.F.; Duarte, E. R.; Geraseev, L.C.; Souza, P.N.S.; Souza, M.F.; Mairink, J.A.M.; Gonzaga Jayme, D.; Lago, L.A. Toxicidade de Annona crassiflora sobre ovinos em teste de campo: relato de caso. Veterinária e Zootecnia, 18: 622-624, 2011.

Raza, A.; Kopp, S.R.; Bagnall, N.H.; Jabbar, A.; Kotze, A.C. Effects of in vitro exposure to ivermectin and levamisole on the expression patterns of $\mathrm{ABC}$ transporters in Haemonchus contortus larvae. International Journal for Parasitology: Drugs and Drug Resistance, 6(2): 103-15, 2016.

Santos, D.Y.A.C.; Salatino, M.L.F. Foliar flavonoids of Annonaceae from Brazil: taxonomic significance. Phytochesmistry, 55(6): 567-573, 2000.

Santos, J.M.L.; Monteiro, J.P.; Ribeiro, W.L.C.; Macedo, I.T.F.; Araujo-Filho, J.V.; Andre, W.P.P. High levels of benzimidazole resistance and $\beta$-tubulin isotype 1 SNP F167Y in Haemonchus contortus populations from Ceará State, Brazil. Journal Small Ruminants, 146: 48-52, 2017. 